\title{
Profile and Marketing Strategy of SME’s Towards Jambi Batik
}

\section{Tony Nawawi*, Rodhiah Husin and Zahrida Zainal Wiryawan}

Tarumanagara University, Jakarta, Indonesia

\begin{abstract}
One of Indonesian culture that is an asset of the ancestors and must be preserved is batik. Almost every province of Indonesia has a unique batik. But not all regions of Indonesia can maintain and preserve the batik industry. One of the main problems in batik products in Jambi lies on marketing aspect. This research aims to design various marketing strategies (product, price, place, promotion). So that Jambi Indonesian batik can keep growing both local and international market. Researched as many as 10 SMEs Jambi batik by way of purposive sampling. Data were collected by using observation, interview and FGD to business owners, employees, cooperatives, and consumers. The research analysis was conducted qualitatively using interactive model. The result of this study pictures that batik entrepreneurs in Jambi comes from hereditary business, from generation to generation. The business potential is huge to be further improved. From marketing strategy including product strategy, price, distribution and promotion have been done. But it has not been done optimally. So it needs to do some improvements so that the strategy can be done more optimal. There are still some issues that need to be improved, such as from product strategy: it is necessary to plan batik innovation into ready-made clothing not only batik cloth. From price strategy: need to create cheap price that can compete with batik price from Java island. From the distribution strategy: the product should not just wait to find a wider market. From the promotion strategy: to better utilize the technology, in order to reach the overseas market. Through the improvement is intended for SMEs Jambi batik can face competition with other business sub-sectors. Thus Jambi batik continues to be preserved its existence.
\end{abstract}

Keywords: Profile; Marketing strategy; SMEs Jambi batik

\section{Introduction}

Small and Medium Enterprise (SME) is one of the assets that has a very important role in the national economy. Such asset may include: sources of employment, equitable distribution of development outcomes, and poverty alleviation. Caused of that, it needs to get attentions and supports from various parties. According to Hafsah [1], developing SMEs need to get a great attention both from government and society, in order to grow more competitive with other economic actors. The capital that is the main issue for SMEs is marketing. According to Winarni [2] and Situmorang [3] there are some things that become the main problem faced by UKM in doing Strategy of small and medium business development are: (a) lack of capital, (b) difficulties in marketing, (c) with non-standard division of labor, (d) quality of management.

Every organization must have marketing strategy in conducting its business activities. The strategy is an organizational tool used to achieve its objectives, as Tapia et al. [4] suggests one form of business strategy is a marketing strategy [5]. But many cases of SMEs in Indonesia are not able to do the right marketing strategy. The tendency of SMEs in Indonesia is just "waiting for consumers" and monotonous in doing marketing activities. The concept of marketing management mentions that the main goal in achieving the target organization consists of (1) the success of achieving the marketing target and (2) to provide more effective and more efficient customer satisfaction. Therefore, each organization must have marketing strategies that must be executed in carrying out its business activities.

The study of these factors is mostly done by researchers with different industry sectors. This research will be conducted on the development of SME Jambi Batik associated with the marketing aspect of SME Jambi Batik in the province of Jambi. Related to this matter, there are some research problems are: 1). How is the profile of Jambi Batik SMEs. 2). How to design marketing strategy related to the product, the price, the place and the promotion that need to be done in developing Jambi batik business?
As for the purpose of the study is to know the description of SMEs business, explaining marketing strategies undertaken in product reviews, prices, place and promotion in order to develop and preserve the existence of Jambi batik.

\section{Literature Review}

Small Business under Law No. 9, 1995, is a small-scale productive enterprise and meets the criteria of net worth of at most Rp.200.000.000,00 (two hundred million rupiah) excluding land and building of business premises or having the most sales proceeds many Rp.1.000.000.000,00 (one billion rupiah) per year and can receive credit from bank maximum above Rp.50.000.000,00 (fifty million rupiah) up to Rp.500.000.000,00 (five hundred million rupiah ).

Medium Enterprises according to In press no. 5 Year 1998, is a productive business that meets the eligibility of wealth criteria bigger than Rp 200,000,000.00 (two hundred million rupiah) up to a maximum of Rp 10,000,000,000.00 (ten billion rupiahs) not including the land and building of the place of business and can receive credit from the bank of Rp.500.000.000,00 (five hundred million rupiah) up to Rp.5.000.000.000,00 (five billion rupiah). Other criteria, the type of business seen from the number of employees (labor) employed by the Central Bureau of Statistics (BPS) are as follows: an enterprise that employs no more than 4 (four) persons is a household or micro enterprise, if employing between 5 (five) persons up to 19 (nineteen persons) are small businesses, employing between 20 and 99 employees

*Corresponding author: Nawawi T, Tarumanagara University, Jakarta, Indonesia Tel: 6281906461741; E-mail: tonyn@fe.untar.ac.id

Received November 20, 2017; Accepted December 20, 2017; Published December 27, 2017

Citation: Nawawi T, Husin R, Wiryawan ZZ (2017) Profile and Marketing Strategy of SME's Towards Jambi Batik. Bus Eco J 8: 334. doi: 10.4172/2151-6219.1000334

Copyright: ( 2017 Nawawi T, et al. This is an open-access article distributed under the terms of the Creative Commons Attribution License, which permits unrestricted use, distribution, and reproduction in any medium, provided the original author and source are credited. 
are medium-sized enterprises and those employing 100 more are large companies.

Strategy formulation is the process of preparing the steps forward intended to build the vision and mission of the organization. Some marketing strategies include [6]

\section{Product}

Kotler [7] says product is everything that can be offered into the market to be noticed, owned, used and consumed so as to satisfy the wants and needs.

\section{Price}

Price, is an important marketing mix tool because it expresses a firm and clear repayment of the products obtained. Explains the price is the amount of money or product needed to obtain another product.

\section{Place}

Place (Distribution Channels) Once the goods are ready to be marketed, the next step in the marketing process is to determine the method and route that will be used to deliver the goods to the market, Kotler and Keller [7]. The distribution of a product will be intensive when the product is placed in many stores to meet market needs.

\section{Promotion}

Kotler and Keller [7] understanding of promotion is: Promotion is a tool in use to inform, affect and remind to consumers of products offered by the company.

Through some marketing strategies it can be said that marketing strategy is a process that enables organizations to centralize resources at the optimal opportunity with the aim of increasing sales and achieving sustainable competitive advantage [8]

\section{Research Method}

\section{Research stages}

To achieve the ultimate goal, then the research can be organized into four stages as follows:

1. To identify natural resources, a business unit of SME, the skill/the ability of entrepreneurs, community culture, as well as, the potential of SMEs, location, business development, using interviews and field observations.

2. To conduct a mapping location and batik SMEs.

3. The focus of the problem on marketing is in doing marketing strategy mixed with SME, so as to design the model of marketing strategy, through FGD with the SME actors, service related to industry /cooperative to accomplish the model.

\section{Population and sample selection technique}

The population in this study is all of SMEs Batik in Jambi City. Method of determining the research sample is purposive sampling, that is by criteria based on the business in the category of SMEs (Small - Medium Enterprises), is a Jambi batik SME with the production process is still using conventional way of not using equipment/ modern machines, companies aged at least five years in producing and marketing the batik industry, running continuously and there are efforts to develop it [9-12]. The total samples selected are 10 SMEs, chosen from several locations of batik SMEs. Data collection technique is done by field observation and in-depth interview. It can be documented (Figure 1).

To answer the problems faced by batik SMEs that have been selected as research samples, the following stages are used:

1. Conducting a profile analysis of the location of batik, batik motifs, SME profile used as sample research

2. Analysis of marketing strategy is an analysis that describes the application of marketing strategy through Product strategy, price, distribution, promotion.

\section{Research result}

The center of Jambi batik is located at Jalan KH M. Ja'Far Mudung Laut, Seberang, Jambi. This area is quite nice because it is closed to the Batang Hari River [13]. Many also come to visit for a day trip along the river Batang day. At night, it is beautiful seeing along the Batang Hari River (Figure 2).

The beauty of this nature needs to be preserved and preserved, local government needs to make tourist attractions along the Batanghari River into a tourist attraction that can be known overseas [14]. And along the road, there are kampung batik and batik studio. This condition should be strived to become a tourist attraction that can be better known by the public, even making overseas attractions.

The production of Jambi Batik is centered in Desa Jambi Seberang (Jambi Opposite village), the residence of the Native Jambinese. In this place, built batik house known as batik studio, which serves as a center Jambi batik craftsmen. There, the batik crafters can introduce batik products. Because the majority of immigrants do not come to the craftsman's house but looking for batik centers. So the area of batik marketing is more centered in the studio. The shape of batik studio is shown in the following picture (Figure 3).

\section{Jambi Batik Motif and explanation}

At first, Jambi batik worn among the royal kingdom. So no wonder if one of the Jambi batik motifs can be a good reference $[15,16]$. This is because the history of Jambi batik comes from the noble class. Thus, the fair nobility of his time has characteristic style and color of course
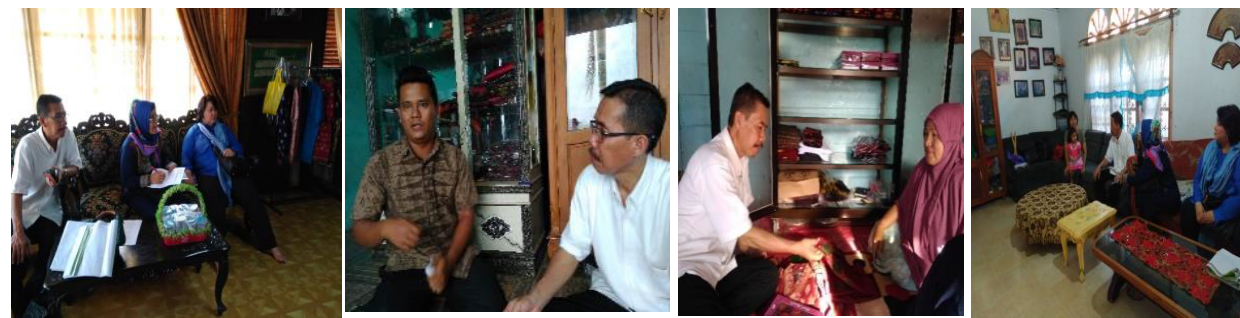

Figure 1: Data collection technique is done by field observation and in depth interview. 
Citation: Nawawi T, Husin R, Wiryawan ZZ (2017) Profile and Marketing Strategy of SME's Towards Jambi Batik. Bus Eco J 8: 334. doi: 10.4172/21516219.1000334
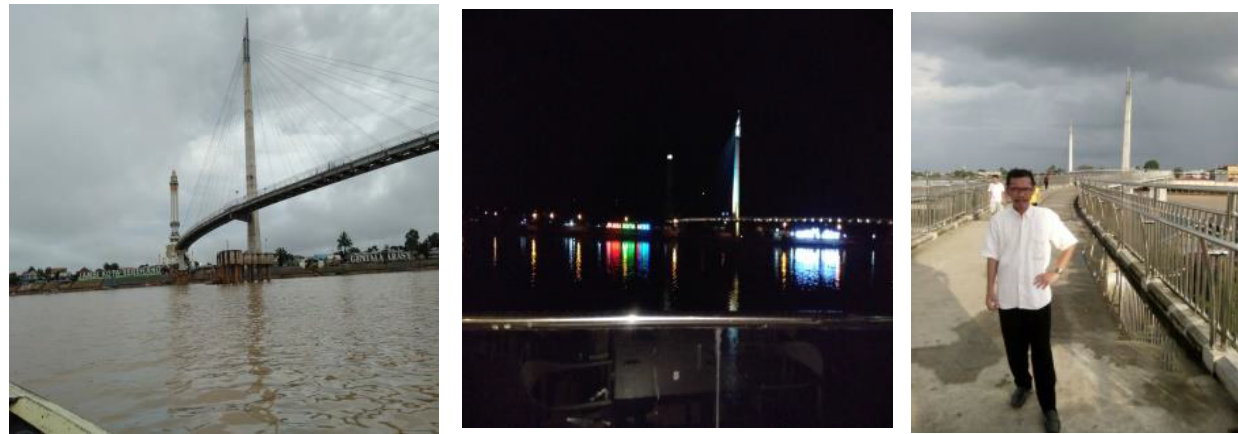

Figure 2: The center of Jambi batik is located at Jalan KH M. Ja'Far Mudung Laut, Seberang, Jambi.
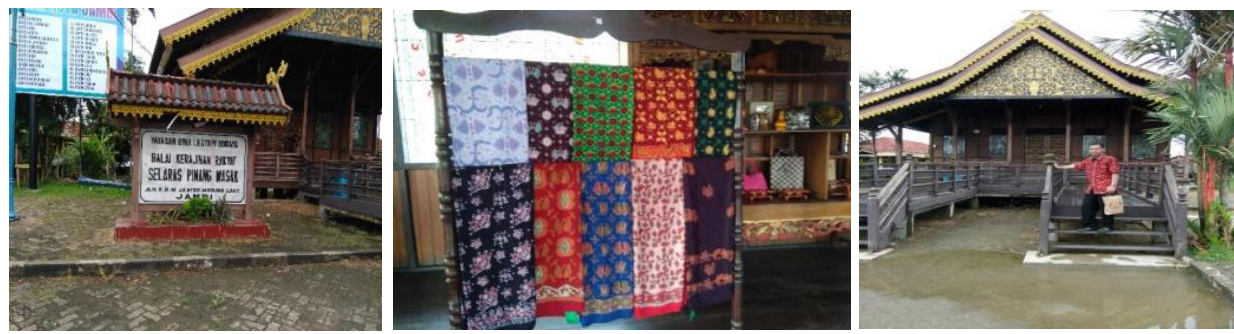

Figure 3: The shape of batik studio.
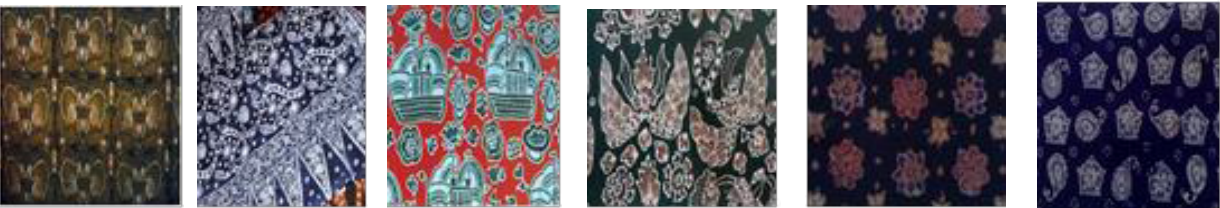

Figure 4: Famous motifs in jambi are Motif Kuao Berhias, Motif Bungo Pauh, Motif Kapal Sanggat, Motif MerakNgeram, Motif KacaPiring, Motif Btanghari.

produce a luxurious impression, elegant, and has a profound meaning. In addition the motifs are inspired from the surrounding environment of Jambi, such as animals and plants. The well-known Jambi batik motifs such as, chicken, wine, fungus, loafers, glass plate (kacopiring), butterfly, flower, durian, taro, two geese (angso duo), and others. The coloration was still using natural materials taken from the jungle around Jambi. These natural dyes produce dazzling and different colors of chemical dyes.

The uniqueness of this batik is the motif that never shows a series of things, meaning is the impression of a separate batik image [17]. Some names of famous batik motifs of Jambi Batik are as follows: Bungo Pauh motif (Pauh is a district in Sarolangun, Jambi, Indonesia.), Batanghari, Kapal Sanggat, Durian Pecah, Kuao Berhias, Merak Ngeram Motif, Tampok Mangosteen Motif, Glass Plate, bungo keladi, Angso Duo Wing and others. which has a different impression impression. There are some famous motifs in Jambi (Figures 4-6).

Many motifs of Jambi batik have a meaning for the introduction of science, then some other motifs depict a meaning of faith and devotion in order to be able to do all the work well and maximally, then some meaning that shows the wisdom of Jambi city culture, geographical and also some beliefs of all customs appear on every motif that is displayed from each of each motif.

\section{SME Jambi Batik description}

The study was conducted on batik SMEs located in Jambi area.

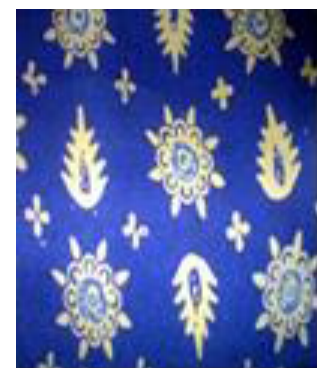

Figure 5: Famous motifs in jambi: Motif Jambi Motif AngsaDua.
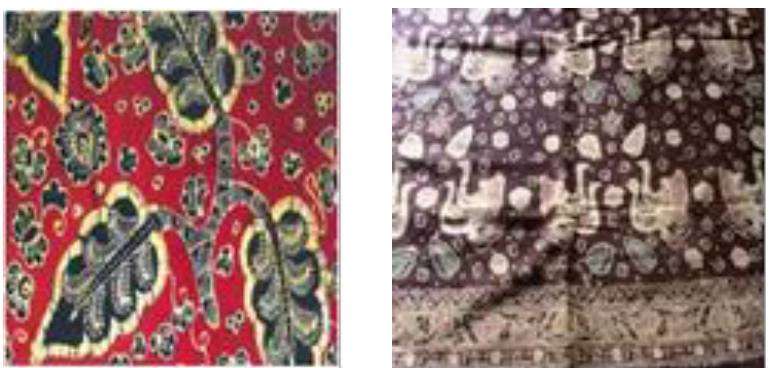

Figure 6: Famous motifs in jambi: Motif TampukManggis, Batik Jambi Motif Bungo Keladi. 
Citation: Nawawi T, Husin R, Wiryawan ZZ (2017) Profile and Marketing Strategy of SME's Towards Jambi Batik. Bus Eco J 8: 334. doi: 10.4172/21516219.1000334

Where the respondents are sampled in this study is 20 SMEs batik craftsmen. The characteristics of respondents are in Table 1.
Through the profile ofbatik craftsmen, seen that most of the business comes from generation to generation. In fact there are some

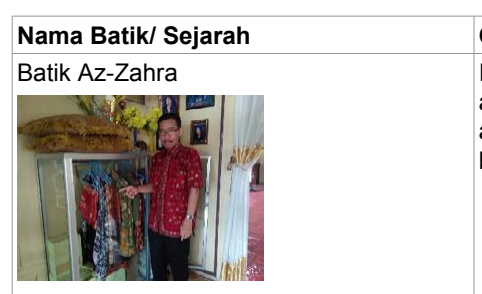

Batik CempakaPutih

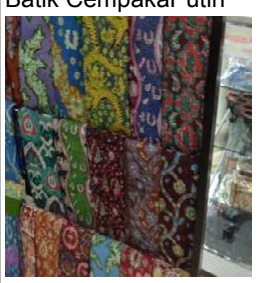

Batik Ariny

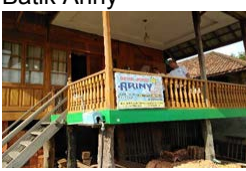

Batik Zhorif

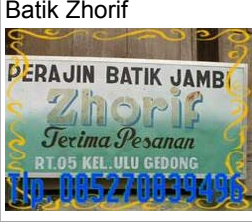

Batik Azmiah

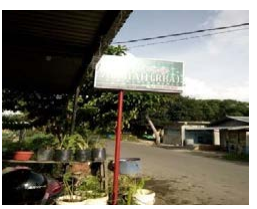

Batik Mirabella

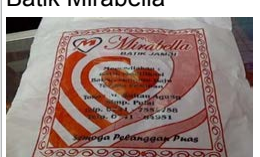

Batik Al-Hadad

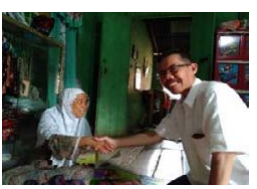

Melati Putih

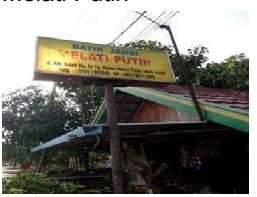

Batik Rezeki

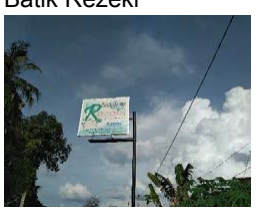

\section{Owners' Name, Age and Length of Business}

Ibu Khodijah is a batik owner, aged 40 years. The location of the business uses shelter in the cloudy sea. own home Initially only as a freelance craftsman. Then make your own effort to make batik with a mediocre capital. Only able to make batik in smal amount. Age of business is 5 years. Still classified as younger than other craftsmen. But have the resolve and interest to be able to make batik independently, not as a freelancer again.

Mrs. Rosi is the owner of batik cempaka putih which is located at Jl. Prof. Dr.Soemantri Brojonegoro No.56 Simpang pulai Jambi, 46 years old. Started business since 2000. Initially only as a freelance craftsman for 20 years. Interested to open your own business with little capital managed to make and sell yourself some batik. Until now still doing business despite the limited capital

Mr. Taufik and Eva Susanti are batik business owners, located at jl.Kyai Haji Muhammad Saleh, no.03. PasirPanjang, Teluk Lake, Jambi City. 46 years old. Developing business Homemade Batik for 19 years, managed independently starting from a fairly minimal capital. Serving the needs of Jambi batik uniforms for school or Madrasah as well as community organizations. Currently have a container of Learning How to Batik with Batik name Jambi Ariny Home Schooling the only one in Jambi. The purpose of Mr. Taufik for young generation interested and interested in learning batik. So later the young generation who wil develop and preserve batik. Teruma in Jambi finds it difficult to find a talented mentor, as well as an interest in making batik. With this home schooling, Mr. Taupik hopes to provide young people in Jambi to preserve Jambi batik.

This is an original Jambi batik business built a craftsman named Atiah Muhammad who has been pioneered since 1982 Located on JI. KH. Ibrahim RT 02 sub districts of business to a wider market. For that Batik craftsmen Jambi ZhorifTelukbay , a woman born in Jambi city has successfully built her batik business until now. A Jambi Batik craftsmen,Zhorif is now trying to develop the trying to improve the quality and performance in providing services to consumers.

Azmiah binti Jancik and Mr. Edi Sunarto, is the second generation pioneer from his mother named Asmah who pioneered batik since 1970. Located on JI. KH.A. Somad No. 41 Kelurahan Olak KemangTelukTeluk District, Jambi. Then, with the support of his mother, on July 20,1984, Kreasi Batik Azmiah, in 2014 Kreasi Batik Azmiah (Creative Batik Azitatif) changed its name to Rumah Batik Azmiah (Rumah Batik R BA Azmiah). The Batik is well known to overseas and has been awarded for 3-Stars OVOP Products from the Ministry of Industry, which was received in Jakarta, on December 24, 2013.

Founded by the father of a woman named Maya. Located on Jalan Sumantri Brojonegoro, Simpang Pulai, Jambi business is already a hereditary business, the first held by his father. Now Maya is the one who continues it. Currently it has a place of production and shop that is quite spacious and well ordered. Besides, it also has employees in the production and stores that petrified Maya's mother in developing his batik business

Mrs. Maryam is the owner of Al-Haddat batik, located on JI. KM. M. Jakfar No.43 Mendung Laut, Jambi Airing Disctrict. Longe business since 1980. Originally Maryam's mother was as a freelance craftsman. Gradually, theyopen their own business. This residence is also used to make batik and batik at the same time.

RTS. Hasnah H M is the owner of Melatiputih batik. Located at JIn KH Saleh RT01 No52 Tanjung Raden,Danau Teluk-Seberang Jambi city. Already done business from 1990. As a successor to the business parents of Hasnah mothers, she intended to expand their business. Currently batik business is quite developed withthe existence of batik studio has been instrumental to assist marketing activities. Mrs Hasnah aspires to develop her batik until foreign countries. Currently the production is also sold in own store. And already have 2 stores in the city of Jambi. So that not only sell in retail but also serve wholesale.
Sania is a business owner bati sustenance 53 years old. Attended training in the early era of 1980 . Learn to make batik from scratch. Starting from how to make motifs, batik, coloring, immersion, and so on. Then the sonya's mother found a business with the name Rezeki. Located at Jln KH Saleh RT07 Kel Ulu Gedong Kec Lake bay across from Jambi city. Sania's mother also supplies batik from several artisans in her village of Tanjung Raden. Tanjung Raden is one of the centers of batik production in Jambi. For Sonia batik jambi give life to Sania who married in 1983. From batik business, Sania can support family with five children till college. 


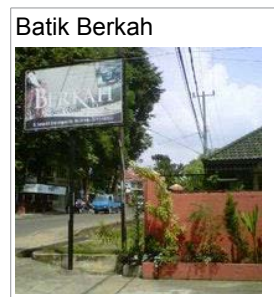

Batik Nurmah

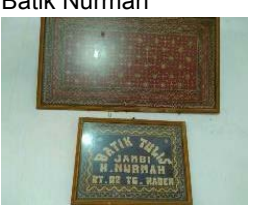

Mahmuda is the owner of batik blessing, located at Simpang Pulai Mangga Jl.Husni Thamrin Jambi. Always looking for inspiration in the development of batik motifs that remain characterized by natural nuances Jambi Mahmuda claimed he often came to Mesium Negeri Jambi to study the history of the past and the struggle of Jambi people who save a lot of local wisdom that can be poured into the idea of creation of new motives, "All craftsmen batik always find a new motif that remains characterized by the nuances of nature and culture of Jambi.

Table 1: The respondents are sampled in this study are 20 SMEs batik craftsmen.

craftsmen is the second generation. However, this generation is over the age of 40 years and some even 65 years [18-20]. This condition is because there is no third generation as the successor of the business. Therefore, to encourage the young generations in this area, they are given batik learning supplies and held by the Office of industry and batik craftsmen such as Craftsmen Ariny, the Opportunity to provide courses to the younger generation. This is so that later the existence of Jambi batik can continue to be preserved its existence.

\section{Jambi Batik product marketing mix strategy}

Product strategy: Products offered include; Batik tulis (handmade batik), Batik cap (stamp batik) Offering good quality with double process. Producing Batik Shirts, Combinations batik, Batik Fabrics (Materials), Batik Calligraphy, Women Batik cloth, etc. Making batik a combination of handmade batik and stamp batik. Make a quality product because it uses a smooth cotton material. The design he made mostly about the flora and fauna and the icon of the city of Jambi such as cotton, angso duo (two geese), durian pecah (broken durian), Kapal Sanggat (sanggat ship), KerisSiginjai, Burung Kwau (Kwau Birds), to the Batanghari river. The uniqueness of this batik is a motif that never shows a series of things, meaning here is the impression of a separate batik image. And Batik limited edition Batik produced in limited quantities due to its unique model. Design motif made mostly about the flora and fauna and icons of Jambi city such as cotton, angso duo, broken durian, ship sanggat, Keris Siginjai, Kwau Birds, to the river Batanghari. While good colors prefer the natural color. Product packaging using paper bag.

Price strategy: The price set by Jambi batik, refers to the amount of cost incurred. Including the type of materials used. The smoother the materials used, the more expensive the price will be. In addition, batik motifs are quite time-consuming in the process will be sold at high prices. Prices are also relatively in line with the quality of the products sold. There are various price variations has been set that is around $\mathrm{Rp}$. 150,000 to Rp. 4 million. Discounts are made by purchasing a large party. But not much, it is also based on the period of batik making process. The longer the process of making the batik tends to become more expensive.

A place/place strategy is a way to distribute products to reach the hands of consumers. Most of the Jambi batik craftsmen distribute directly from their hauses that is waiting for consumers. There are also through their own kiosks. Most of the products are distributed through sanggar (batik house/studio) built by local government. There are also batik business men who have been able to support through overseas markets.

\section{Promotion strategy}

Promotions that are applied by good business owners mostly use WOM and exhibitions. Along with technology changes there are some batik craft sment that utilize online media, social media, and catalog.

\section{Result and Conclusion}

Through the analysis that has been conducted in this study hence it can be compiled several conclusions, those are:

1. Description of the business location of the craftsmen is strategic. On the outskirts of Batanghari river tourist spot.

2. Based on the product strategy of SMEs Batik, has a variety of motifs and traditions, describing the city of Jambi. Natural coloring and packaging of paper bag products. Overall using quality materials based, so the results of products created quality not fade and interesting color.

3. Based on the selling price strategy, it varies from Rp. 150 thousand to RP. 4 million. The price is adjusted with the duration of the process of batik making, raw materials used and type of fabric.

4. Based on place Strategy, generally use direct distribution strategy. The finished goods are put in the display window/hung in batik artisans house. Then wait for buyers to shop directly to the craftsmen and to the studio.

5. Based on promotional strategy. During this time more emphasis on words of mouth strategy (WOM), and follow the exhibition by local government. But through some technology, batik already rely on social media. Though it still not well managed.

\section{Suggestion}

1. Center of batik is located on the outskirts of the Batanghari river, so the attractions along the river need to be better organized.

2. Product innovation of the model needs to be improved in order to face the possibility of entry of new competitors.

3. Cheap strategies need to be created to counterbalance batik pulau (Island batik) from Java Island.

4. The distribution of product needs to be expanded to increase the market.

5. Promotion activities need to be intensified both with print and electronic media. So that it can spread information about the existence of Jambi batik to foreign countries. 
Citation: Nawawi T, Husin R, Wiryawan ZZ (2017) Profile and Marketing Strategy of SME's Towards Jambi Batik. Bus Eco J 8: 334. doi: 10.4172/21516219.1000334

\section{References}

1. Hafsah MJ (2004) Upaya Pengembangan Usaha Kecil dan Menengah (UKM). Infokop 25: 40-44.

2. Winarni ES (2006) Strategi Pengembangan Usaha Kecil melalui Peningkatan Aksesibilitas Kredit Perbankan.

3. Situmorang J (2008) Strategi UMKM dalam Menghadapi Iklim Usaha yang Tidak Kondusif. Infokop 16: 88-101.

4. Tapia IM, Correa JAA, Manzanares AR (2010) Environmental strategy and exports in medium, small and micro-enterprises. Journal of World Business 45: $266-275$.

5. Sara J (2010) The impact of institutional impediments and information and knowledge exchange on SME's investments in international business relationships. International Business Review 19: 548-561.

6. Yoo B, Donthu N, Lee S (2000) An examination of selected marketing mix elements and brand equity. Academy of Marketing Science Journal 28: 195-211.

7. Kotler P, Keller KL (2003) Marketing Management. (14th edn.), New Jersey: Prentice Hall Published.

8. Bei LT, Shang CF (2006) Building marketing strategies for state- owned enterprises against private ones based on the perspective of customer satisfaction and service quality. Journal of Retailing and Consumer Services 13: $1-13$

9. Sofjan A (2008) Manajemen Pemasaran, edisi kesatu, cetakan kesembilan Penerbit: Raja Grafindo Persada, Jakarta.
10. Suharsimi A (2005) Prosedur Penelitian Suatu Pendekatan Praktik. Jakarta: Rineka Cipta.

11. Lesceviva M (2004) Rural Entrepreneurship Success Determinant, Unpublished Working Papers, Latvian University of Agriculture, Eksjo, Latvian.

12. Moleong LJ (2002) Metodologi Penelitian Kualitatif. Bandung: PT. Remaja Rosdakarya.

13. Ina $P$ (2009) MenggerakanSektor Rill UKM \&Industri. Bandung: Alfabeta.

14. Sekaran U, Bougie R (2004) Research Methods For Business: A Skill-Bulding Approach. John Wiley \& Sons, New York, USA.

15. Soeprihanto J, Sunarni M (2010) Pengantar Bisnis (Dasar-dasar Ekonomi Perusahaan). Liberty Yogyakarta.

16. Sriram S, Chintaguta PK, Neelamegham R (2006) Effects of Brand Preference, Product Attributes and Marketing Mix Variabels in Technology Product Markets. Journal Marketing Science 25: 404- 456.

17. Tambunan $T$ (2005) Promoting Small and Medium Enterprises with a Clustering Approach: A Policy Experience from Indonesia. Journal of Small Business Management 43: 138-154.

18. Umar H (2008) Strategic Management in Action.

9. Zimmerer TW, Scarborough NM, Wilson D (2008) Essentials of Entrepreneurship and small business management. 5th edition, Pearson Education Inc, New Jersey.

20. Zeithaml VA (1998) Consumer Perceived of Price, Quality and Value: A MeansEnd Model and Synthesis of Evidence. Journal of Marketing. 